Article

\title{
Analysis of Urban Green Spaces Based on Sentinel-2A: Case Studies from Slovakia ${ }^{\dagger}$
}

\author{
Monika Kopecká ${ }^{1, *}$, Daniel Szatmári ${ }^{1}$ and Konštantín Rosina ${ }^{2}$ \\ 1 Institute of Geography, Slovak Academy of Sciences, Štefánikova 49, 81473 Bratislava, Slovakia; \\ geogszat@savba.sk \\ 2 Joint Research Centre, European Commission, Via E. Fermi 2749, I-21027 Ispra, Italy; \\ konstantin.rosina@ec.europa.eu \\ * Correspondence: monika.kopecka@savba.sk; Tel.: +421-2-57510218 \\ + This paper is extended from the version presented at the 6th International Conference on Cartography and \\ GIS, Albena, Bulgaria, 13-17 June 2016.
}

Academic Editors: Andrew Millington and Harini Nagendra

Received: 8 March 2017; Accepted: 10 April 2017; Published: 14 April 2017

\begin{abstract}
Urban expansion and its ecological footprint increases globally at an unprecedented scale and consequently, the importance of urban greenery assessment grows. The diversity and quality of urban green spaces (UGS) and human well-being are tightly linked, and UGS provide a wide range of ecosystem services (e.g., urban heat mitigation, stormwater infiltration, food security, physical recreation). Analyses and inter-city comparison of UGS patterns and their functions requires not only detailed information on their relative quantity but also a closer examination of UGS in terms of quality and land use, which can be derived from the land cover composition and spatial structure. In this study, we present an approach to UGS extraction from newly available Sentinel-2A satellite imagery, provided in the frame of the European Copernicus program. We investigate and map the spatial distribution of UGS in three cities in Slovakia: Bratislava, Žilina and Trnava. Supervised maximum likelihood classification was used to identify UGS polygons. Based on their function and physiognomy, each UGS polygon was assigned to one of the fifteen classes, and each class was further described by the proportion of tree canopy and its ecosystem services. Our results document that the substantial part of UGS is covered by the class Urban greenery in family housing areas (mainly including privately-owned gardens) with the class abundance between $17.7 \%$ and $42.2 \%$ of the total UGS area. The presented case studies showed the possibilities of semi-automatic extraction of UGS classes from Sentinel-2A data that may improve the transfer of scientific knowledge to local urban environmental monitoring and management.
\end{abstract}

Keywords: urban green spaces; Sentinel-2A; ecosystem services; Slovakia

\section{Introduction}

Urban expansion is occurring at an unprecedented rate. By 2020, approximately $80 \%$ of Europeans will be living in urban areas, while in seven countries, the proportion is expected to be $90 \%$ or more [1]. Although urban areas remain a relatively small fraction of the terrestrial surface (in 2012, artificial surfaces covered $4.4 \%$ of land in Europe [2]), the urban ecological footprint widely extends beyond city boundaries, and urban expansion is impacting heavily on ecological processes [3]. Ecologists have studied the relationship between urban biodiversity and socioeconomic patterns in cities since the 1970s [4]. For example, a study of vegetation in neighbourhoods in Chicago, Illinois, USA, related patterns of tree species richness to census tract block data for the neighbourhoods [5]. Research on street and yard trees [6] aimed to identify census and other socioeconomic predictors of species richness. Two urban maps of the city of Osnabrück, Germany [7], represented the socio-economic distribution 
of the human population and the distribution of plant communities. The comparison reveals that both distributions are closely linked. These studies attempted to relate patterns of biodiversity to specific types of neighbourhoods, thus building on ideas that were linked to theories about differentiation and spatial patterns in cities [4].

The diversity and quality of urban green spaces (UGS) such as parks, forests, green roofs, or community gardens are tightly linked to human well-being as UGS provide a number of ecosystem services for people. In recent years, many studies advanced our understanding of UGS in their biophysical, economic and socio-cultural dimensions. The crucial ecosystem service of urban vegetation is its regulatory effect on the urban microclimate [8]; other relevant benefits are stormwater infiltration, food security, physical recreation, and psychological well-being of residents [9-11]. It is also known that the percentage of green space in people's living environment has a positive association with the perceived general health of residents [12].

By definition, ecosystem services have societal relevance: they provide benefits that humans want or need. The Economics of Ecosystem Services and Biodiversity-TEEB Manual for Cities [13] grouped ecosystem services in four major categories: provisioning, regulating, habitat and cultural and amenity services. In the process of spatial planning, all these desired outcomes must be identified and compared to the current potential of the UGS. Analyses and inter-city comparison of UGS patterns and their functions require not only detailed information on their relative quantity but also a closer examination of UGS in terms of quality and land use, which can be derived from the land cover composition and spatial structure.

The spatial structure of impervious-vegetated mix is heterogeneous at much finer scale in urban landscape than elsewhere. As a result, for a long time, conventional methods of mapping urban vegetation have relied on a visual interpretation of aerial images and fieldwork. More recently, developed very high resolution (VHR) satellite remote sensing systems (IKONOS, QuickBird, GeoEye, RapidEye, WorldView, Pleiades) are capable of providing imagery with similar detail to aerial photography, and they offer opportunities to overcome the lack of reliable and reproducible information on urban vegetation across large areas [14-16]. However, the disadvantage of VHR satellites is their narrow swath and therefore limited coverage of the Earth's surface. Besides, the VHR satellites are commercially oriented services, and the data cost is relatively high.

One of the most recent sources of information on land cover, including UGS, is Sentinel-2A (S2A), a high-resolution optical Earth observation mission. Although it has coarser spatial resolution than the VHR satellites, it offers higher spectral resolution and is provided free of charge. Sentinel missions are part of the Copernicus program (previously called GMES), a joint initiative of the European Commission and European Space Agency to establish a European capacity for the provisioning and use of information for environmental monitoring and security applications.

The objectives of this study are to:

1. Apply a methodical procedure of UGS extraction from S2A satellite imagery to selected study areas.

2. Analyse the UGS composition in the context of ecosystem services and identify UGS major components typical for cities in Slovakia.

3. Present the results of UGS comparative analysis in three regional cities in Slovakia: Bratislava, Trnava and Žilina.

\section{Materials and Methods}

\subsection{Data}

The S2A multispectral imager covers 13 spectral bands with a swath width of $290 \mathrm{~km}$ and spatial resolutions of $10 \mathrm{~m}$ (three visible and a near-infrared band), $20 \mathrm{~m}$ (6 red-edge/shortwave infrared bands) and $60 \mathrm{~m}$ (3 atmospheric correction bands). The mission is intended to monitor variability in land surface conditions, and its wide swath width and high revisit time (10 days with one satellite and five days in full constellation with twin satellite Sentinel-2B) will support monitoring of changes 
to vegetation within the growing season. It also provides data and applications for operational land monitoring, emergency response, and security services. The coverage limits are from between latitudes $56^{\circ}$ south and $84^{\circ}$ north.

The 100\% cloud-free S2A scenes acquired in August 2015 (study area Bratislava) and in September 2016 (study areas Trnava and Žilina) were downloaded from Copernicus Sentinels Scientific Data Hub (https:/ / scihub.copernicus.eu/dhus/). We used orthorectified and radiometrically corrected images (processing level 1C). Since the study areas represent only a small fraction of the respective scene's footprint, we have assumed constant atmospheric conditions and no atmospheric corrections were applied. Each scene contains 13 spectral bands with native spatial resolutions of $10 \mathrm{~m}$ (blue, green, red, and near-infrared bands), $20 \mathrm{~m}$ (red edge bands), or $60 \mathrm{~m}$ (short wave infrared bands); all bands were resampled to $10 \mathrm{~m}$ resolution for further processing.

\subsection{Methodology}

Since the proposed classification scheme of UGS is largely land use oriented, it is not viable to obtain the information by automatic methods. Therefore, aerial or very high resolution (VHR) satellite images are needed to perform on-screen interpretation and classification of individual UGS polygons extracted from the S2A data. Finer than $10 \mathrm{~m}$ spatial resolution imagery is useful also in the process of selecting the training samples for supervised automatic classification of the S2A imagery (Figure 1) [17].

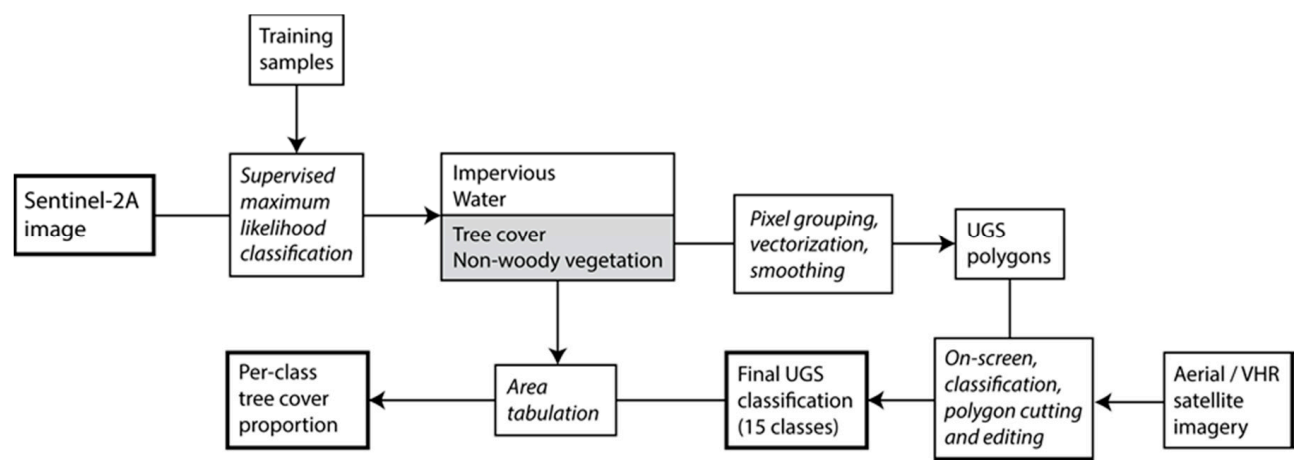

Figure 1. Scheme of the proposed methodology [17].

Given the spectral resolution and bandwidth of S2A data, we assumed that automatic classification methods have the potential to discriminate between a small number of spectrally different LC types with reasonable accuracy. We suggested a simple impervious-water-vegetation classification scheme; the vegetation was further divided into tree cover and non-woody classes. We preferred a supervised approach for higher accuracy. For each of the target land cover classes, a manually pre-classified training sample with a sufficient number of sample plots located evenly in the study area was created. The resulting set of total 435 sample plots (88 in Bratislava, 195 in Trnava and 152 in Žilina) was fed into the commonly used maximum likelihood classifier that was finally employed to perform per-pixel classification of the images. The S2A data were processed and classified using ESA SNAP 3.0 and ESRI ArcGIS Desktop 10 software, respectively. An example of true colour (red-green-blue) (RGB) composite is displayed in Figure 2a. Results of the initial classification are presented in Figure $2 b$. Using the tools for post-classification accuracy assessment in ArcGIS Desktop 10.4 we created 239 randomly sampled points. Reference values interpreted based on VHR satellite images and aerial images available in ArcGIS online Base map were compared with the classification results at the same locations. A summary of the accuracy assessment is presented in Table 1 in the form of a confusion matrix (per study area). The diagonal values for each city represent the correctly classified pixels. The ratio of their sum to the total number of tested pixels gives the total accuracy of the classification. User's accuracy (U Accuracy-rows of the table) shows pixels incorrectly classified as a given class. 
Producer's accuracy (P Accuracy-columns of the table) shows pixels of a known class classified as something else. The Kappa coefficient (a real number from an interval $[0,1]$ ) is an overall assessment of the accuracy of the classification.

To extract the final UGS polygons from the classified images, these were reclassified into a binary form vegetation/non-vegetation. Contiguous pixels classified as vegetation were grouped (based on queen neighbourhood - each pixel can have maximum eight neighbours) and converted to vector polygons (Figure 2c). All polygon parts and holes smaller than $500 \mathrm{~m}^{2}$ were removed. The remaining polygons were smoothed and generalised in order to remove pixelated borders, reduce the size, and improve the visual appearance (see Figure $2 \mathrm{~d}$ ).
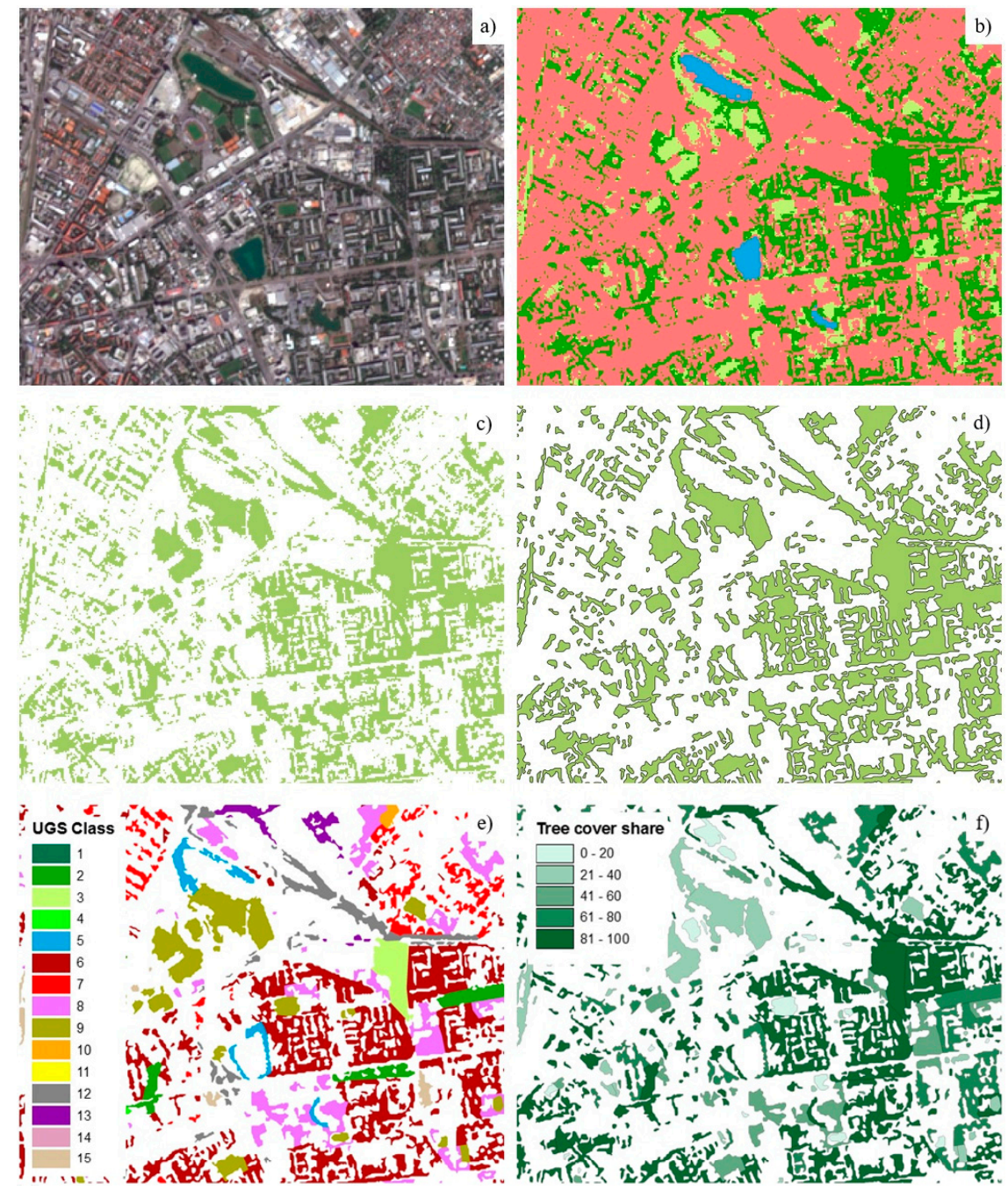

Figure 2. Six processing steps of the UGS extraction and classification (an example from study area Bratislava). (a) A true colour composite produced from S2A data; (b) result of the maximum likelihood supervised automatic classification; (c) binary map of vegetation/non-vegetation land cover; (d) vectorised and visually enhanced polygons with the minimum mapping unit of $500 \mathrm{~m}^{2}$ applied; (e) result of UGS visual interpretation and polygon editing; (f) tree cover share estimated using (b,e) on a per-polygon basis [17].

From the perspective of ecosystem services and urban planning, it is important to consider how the identified UGS are utilised by city residents, the degree of human cultivation/intervention, and location relative to the prevalent use of urban land (residential, public, industrial). Considering these requirements, we recognised 15 classes presented and defined in Table 2. UGS polygons extracted 
in the previous step were overlaid on top of recent aerial orthophotos and visually classified at the scale range 1:10,000-1:5000. Most of the polygons were classified as such by filling the attribute values. In some cases (especially in places with abundant vegetation), the extracted polygons were spanning over larger areas and included multiple UGS classes. In such cases, the polygons were cut so that each polygon contains a single UGS class (see Figure 2e). Additional information useful for decision making is the type of vegetation. We suggest that tree vegetation provides a wider range of ecosystem services compared to herbaceous vegetation. We have therefore estimated the share of tree cover for each polygon (Figure 2f) and UGS class (based on the initial automatic LC classification).

Table 1. Supervised classification accuracy assessment.

\begin{tabular}{cccccccc}
\hline Class Name & Water & Impervious & Tree Cover & $\begin{array}{c}\text { Non-Woody } \\
\text { Vegetation }\end{array}$ & Total & $\begin{array}{c}\text { U Accuracy } \\
\text { (\%) }\end{array}$ & $\begin{array}{c}\text { P Accuracy } \\
\text { (\%) }\end{array}$ \\
\hline Water & 20 & 0 & 0 & 0 & $\mathbf{2 0}$ & 100.00 & 100.00 \\
\hline Bratislava & 10 & 0 & 0 & 0 & $\mathbf{1 0}$ & 100.00 & 100.00 \\
Trnava & 0 & 0 & 0 & 0 & $\mathbf{0}$ & - & - \\
Žilina & 10 & 0 & 0 & 0 & $\mathbf{1 0}$ & 100.00 & 100.00 \\
\hline Impervious & 0 & 107 & 1 & 5 & $\mathbf{1 1 3}$ & 94.69 & 94.69 \\
\hline Bratislava & 0 & 51 & 0 & 1 & $\mathbf{5 2}$ & 98.08 & 96.23 \\
Trnava & 0 & 33 & 1 & 2 & $\mathbf{3 6}$ & 91.67 & 94.29 \\
Žilina & 0 & 23 & 0 & 2 & $\mathbf{2 5}$ & 92.00 & 92.00 \\
\hline Tree cover & 0 & 2 & 39 & 4 & $\mathbf{4 5}$ & 86.67 & 84.78 \\
\hline Bratislava & 0 & 2 & 19 & 4 & $\mathbf{2 5}$ & 76.00 & 95.00 \\
Trnava & 0 & 0 & 10 & 0 & $\mathbf{1 0}$ & 100.00 & 83.33 \\
Žilina & 0 & 0 & 10 & 0 & $\mathbf{1 0}$ & 100.00 & 71.43 \\
\hline Non-woody vegetation & 0 & 4 & 6 & 51 & $\mathbf{6 1}$ & 83.61 & 85.00 \\
\hline Bratislava & 0 & 0 & 1 & 20 & $\mathbf{2 1}$ & 95.24 & 80.00 \\
Trnava & 0 & 2 & 1 & 14 & $\mathbf{1 7}$ & 82.35 & 87.50 \\
Žilina & 0 & 2 & 4 & 17 & $\mathbf{2 3}$ & 73.91 & 89.47 \\
\hline Total & $\mathbf{2 0}$ & $\mathbf{1 1 3}$ & $\mathbf{4 6}$ & $\mathbf{6 0}$ & $\mathbf{2 3 9}$ & & \\
\hline Bratislava & 10 & 53 & 20 & 25 & $\mathbf{1 0 8}$ & & \\
Trnava & 0 & 35 & 12 & 16 & $\mathbf{6 3}$ & & \\
Žilina & 10 & 25 & 14 & 19 & $\mathbf{6 8}$ & & \\
\hline & Overall classification Accuracy (\%): & & $\mathbf{9 0 . 7 9}$ & & \\
\hline
\end{tabular}

Urban ecosystem services have been classified in a variety of ways; most commonly, they are divided into four categories: provisioning services, regulating services, habitat or supporting services, and cultural services [13].

1. Provisioning services are ecosystem services that describe the material or energy outputs from ecosystems. They include providing raw materials, fresh water, food and medicinal resources.

2. Regulating services are the services that ecosystems provide by acting as regulators of local climate and air quality, carbon sequestration and storage, moderation of extreme events, wastewater treatment, erosion prevention and maintenance of soil fertility, pollination and biological control.

3. Cultural services include the nonmaterial, socio-ecological benefits (including psychological and cognitive benefits) people obtain from contact with the environment. They include recreation, physical and mental health (for example walking or playing sports in green areas), tourism, aesthetic appreciation and inspiration for culture, art and design, spiritual experience and sense of place (different sacred places or places with a religious meaning).

4. Habitat and supporting services underpin almost all other services by providing living spaces for organisms. They provide habitats for species and contribute to the maintenance of genetic diversity. 
Table 2. UGS classification and definition of UGS classes.

\begin{tabular}{|c|c|c|c|c|}
\hline No. & UGS Class & Description & Example & Ecosystem Services \\
\hline 1. & $\begin{array}{l}\text { Urban forest/ } \\
\text { Uncultivated park }\end{array}$ & $\begin{array}{l}\text { Areas characterised by more than } 50 \% \\
\text { woody vegetation with no signs of } \\
\text { cultivation and without paved } \\
\text { roads/paths }\end{array}$ & & Habitat \\
\hline 2. & Cultivated park & $\begin{array}{l}\text { Areas characterised by more than } 50 \% \\
\text { woody vegetation with paved paths } \\
\text { and scattered lawns }\end{array}$ & & Cultural \\
\hline 3. & Cemetery & $\begin{array}{l}\text { Areas of cemeteries with } \\
\text { dominant vegetation }\end{array}$ & & Cultural \\
\hline 4. & Urban public garden & $\begin{array}{l}\text { Areas characterised by the regular } \\
\text { shape of lawns, flowerbeds, shrubs, } \\
\text { paths and scattered trees }\end{array}$ & & Cultural \\
\hline 5. & $\begin{array}{l}\text { Stream bank/lake } \\
\text { shore vegetation }\end{array}$ & $\begin{array}{l}\text { Green areas adjacent to ponds, lakes, } \\
\text { rivers, or canals }\end{array}$ & & Habitat/Regulating \\
\hline 6. & $\begin{array}{l}\text { Urban greenery in } \\
\text { apartment housing areas }\end{array}$ & $\begin{array}{l}\text { Public greenery in residential zones } \\
\text { between multi-flat houses and/or } \\
\text { small commercial buildings }\end{array}$ & & Regulating/Cultural \\
\hline 7. & $\begin{array}{l}\text { Urban greenery in family } \\
\text { housing areas }\end{array}$ & $\begin{array}{l}\text { Greenery in residential zones between } \\
\text { family houses, mostly comprising } \\
\text { private horticultural gardens }\end{array}$ & & Provisioning/Cultural \\
\hline 8. & $\begin{array}{l}\text { Urban greenery in } \\
\text { public facilities }\end{array}$ & $\begin{array}{l}\text { Greenery in compact areas with } \\
\text { particular public services, like } \\
\text { hospitals, universities, school } \\
\text { campus, ZOO etc. Sports facilities } \\
\text { are not included in this class }\end{array}$ & & Cultural \\
\hline 9. & $\begin{array}{l}\text { Greenery in } \\
\text { sports facilities }\end{array}$ & $\begin{array}{l}\text { Green areas used for sports and } \\
\text { leisure mainly covered by grass, } \\
\text { such as football field, golf course, } \\
\text { playground, and horse race circuit }\end{array}$ & & Cultural \\
\hline 10. & Allotments & $\begin{array}{l}\text { Area with small parcels of annual } \\
\text { crops, pastures, fallow land and/or } \\
\text { permanent crops, with scattered } \\
\text { garden cabins }\end{array}$ & & Provisioning/Cultural \\
\hline 11. & Cropland/pastures & $\begin{array}{l}\text { Agricultural areas with signs of } \\
\text { cultivation (e.g., tracks from } \\
\text { ploughing or tractor use). This class } \\
\text { contains both cropped areas and areas } \\
\text { with grass in rotation, as well as } \\
\text { orchards and vineyards }\end{array}$ & & Provisioning \\
\hline 12. & $\begin{array}{l}\text { Railway and } \\
\text { roadside greenery }\end{array}$ & $\begin{array}{l}\text { Verge with grass or other } \\
\text { vegetation accompanying a railway, } \\
\text { road or motorway }\end{array}$ & & Regulating \\
\hline 13. & $\begin{array}{l}\text { Green areas in } \\
\text { industrial units }\end{array}$ & $\begin{array}{l}\text { Areas covered by vegetation in } \\
\text { factories with industrial production, } \\
\text { storage facilities, logistic centres, etc. }\end{array}$ & & Regulating \\
\hline 14. & Airport greenery & $\begin{array}{l}\text { Grass areas of airports associated } \\
\text { with runways }\end{array}$ & & Regulating \\
\hline 15. & Ruderal vegetation & $\begin{array}{l}\text { Areas with grass, herbaceous, shrub } \\
\text { and/or scattered woody vegetation } \\
\text { with no signs of recent cultivation. } \\
\text { Usually heterogeneous in texture and } \\
\text { colour. Fallow land and brownfields } \\
\text { can also be part of this class }\end{array}$ & & Regulating \\
\hline
\end{tabular}


Patterns of urban areas have significant implications for biodiversity and ecosystem functions. In this context, each UGS class was categorised according to their expected ecosystem services (Table 2).

Urban forests or uncultivated parks (class 1) as well as stream banks and lake shores (class 5) have become a refuge for many species, especially birds and amphibians. Cultivated parks, cemeteries and urban gardens (classes 2, 3 and 4) play an important role as providers of aesthetic and psychological benefits that enrich human life, reducing stress and increasing physical and mental health $[18,19]$. They are considered to be habitats in a city that truly demonstrate human expression and creativity [4]. Some of them (e.g., botanical gardens) are used also for environmental education purposes. Greenery in sports facilities, such as football pitches or aqua parks (class 9), increases the recreational potential of a city. However, the recreational opportunities of urban ecosystems also vary with social criteria, including accessibility, penetrability, safety, privacy and comfort [20].

Ecological infrastructure in cities regulates local temperatures and buffers the effects of urban heat islands [21]. Water from plants absorbs heat as it evaporates, thus cooling the air in the process [22]. Trees can also regulate local surface and air temperatures by reflecting solar radiation and shading surfaces, such as streets and sidewalks that would otherwise absorb heat. Decreasing the heat loading of the city is among the most important regulating ecosystem services trees provide to cities [23]. These regulating services are dominant in the classes Urban greenery in apartment housing areas and Urban greenery in public facilities (classes 6 and 8). Positive effects of vegetation on human health (cultural ecosystem services) are also important. For example, a view through a window looking out at green spaces could accelerate recovery from surgeries [24] and proximity of an individual's home to green spaces was correlated with fewer stress-related health problems and a higher general health perception [25]. Increasing the impervious surface area in cities leads to increased volumes of surface water runoff, and thus increases the vulnerability to water flooding. Green areas reduce the pressure on urban drainage systems by percolating water.

Urban greenery in family housing areas (class 7) prevailingly consists of greenery in residential zones between family houses, mostly comprising private horticultural gardens that offer multiple opportunities for family leisure activities. Traditionally, private gardens were important for the provisioning of food (usually some sorts of fruits and vegetables) for the city residents. However, in the recent two decades, a significant part of garden fruit trees was replaced by decorative conifers and only a small fraction of food consumed by families is home produced. Similar ecosystem services are provided by the class Allotments (10) represented by community gardens usually owned by people living in multi-flat houses. Despite our effort to exclude agricultural land from the study areas, some cultivated fields cannot be omitted as they are situated within the city area itself (see Chapter 2.3 Study area). They belong to the class 11 Cropland/pastures with provisioning ecosystem services. Air pollution from transportation and industry is one of the major problems for environmental quality and human health in the urban environment. Vegetation in industrial zones, railway, roadside and airport greenery (classes 12, 13 and 14) with dominant regulating ecosystem service improves air quality by removing pollutants from the atmosphere [26]. Vegetation in these localities is also an important factor for noise reduction. Ruderal vegetation (class 15) is typical for unused or abandoned localities. They are often covered by herbs and shrubs that also contribute to the reduction of soil sealing negative effects.

\subsection{Study Areas}

We have selected cities Bratislava, Trnava and Žilina, three of eight regional capitals of Slovakia's NUTS 3 administrative regions, as the study area (Figure 3).

The cities Bratislava and Žilina are located in large river valleys, and the diversified terrain is an important local climate factor; the city of Trnava is located in a flat area. The built-up area of the cities has increased significantly in recent twenty years due to the construction of new automobile plants (Volkswagen in Bratislava, Peugeot-Citroen in Trnava and Kia Motors in Žilina) and large shopping centres in suburban areas. As the rapid increase of impervious surfaces may worsen urban 
heat island effects, well-thought UGS management should play an important role in sustainable development of these cities.

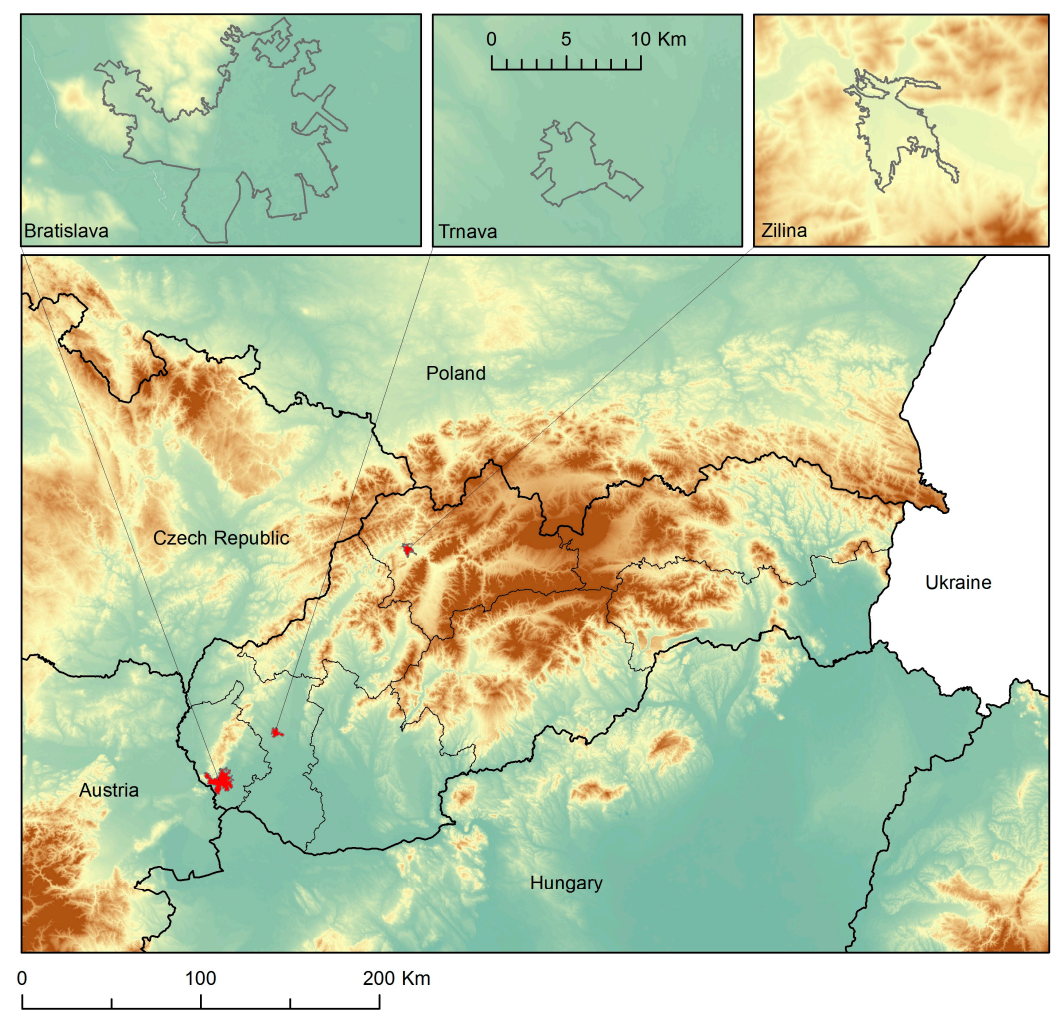

Figure 3. Location of the study areas Bratislava, Trnava and Žilina (Digital Elevation Model Over Europe-EU DEM-Source: http:/ /land.copernicus.eu/pan-european).

The Bratislava study area is situated in the south-west part of Slovakia bordering Austria in the west and Hungary in the south. Bratislava is the capital of Slovakia, the country's largest city and it is the political, cultural and economic centre. Due to this fact and a good quality transport infrastructure, it is a territory with high potential for territorial development. The limiting factor for a further expansion of the city is the Little Carpathian mountain range located north of the city centre. Bratislava lies on the both banks of the Danube River, which crosses the city from the west to the south-east. The population of Bratislava at the end of 2015 was 422,453 inhabitants ( $7.78 \%$ of the population in Slovakia).

Trnava is a city in western Slovakia, $47 \mathrm{~km}$ north-east of Bratislava. It is located in the Danubian Lowland on the Trnávka River in the central part of Trnava Plain. Due to the character of relief, the close position to the capital city of Bratislava and good transport infrastructure, it has a great potential for territorial development. However, the presence of top quality soils in the hinterland of the city is actually a limiting factor for its further expansion. The population of Trnava at the end of 2015 was 65,596 inhabitants.

Žilina is a city in north-western Slovakia, around $200 \mathrm{~km}$ from the capital Bratislava, close to both the Czech and Polish borders. It is the fourth largest city of Slovakia with a population of 81,114, an important industrial centre and the largest city on the Váh River. The city is surrounded by the mountain ranges Malá Fatra, Súl’ovské vrchy, Javorníky and Kysucká vrchovina.

Definition of urban areas and their boundaries vary between countries and regions. Therefore, as the first step of any urban comparative analysis, a common definition of "urban" should be specified. Although the administrative definition of cities has the benefit of wide data availability, such boundaries often include large portions of rural landscape, mostly with agricultural and (semi-) 
natural land cover, which cannot be considered as urban greenery. The focus of this study is on the services and benefits provided by urban ecosystems. Therefore, we suggest that for UGS comparison, a city should be defined rather by its continuously built-up area, where the concentration of people is the highest both during the daytime and night-time, and the density of buildings and other impervious surfaces is so high, that it can alter the microclimate significantly [27]. In the European context, the contiguously built-up area can be delineated based on open data from the Urban Atlas database that has harmonised definition, suitable spatial detail and is updated and validated regularly [28]. Particularly, we extracted all the artificial surfaces from Urban Atlas 2012 (code 1xxxx), excluding road and rail network (which is represented by a single extensive and complex polygon that spans the whole urban region including the commuting hinterland). Consequently, the polygons were buffered by $50 \mathrm{~m}$ and merged (to connect built-up blocks and join gaps in urban fabric up to $100 \mathrm{~m}$ wide). Holes in the resulting polygon were filled, and the result was buffered back by $50 \mathrm{~m}$. This method produced an accurate picture of the selected cities (Figure 4), where only minor manual editing was needed. Additionally, this definition can be applied to any EU city and can be updated on a six-year basis to account for city expansion.

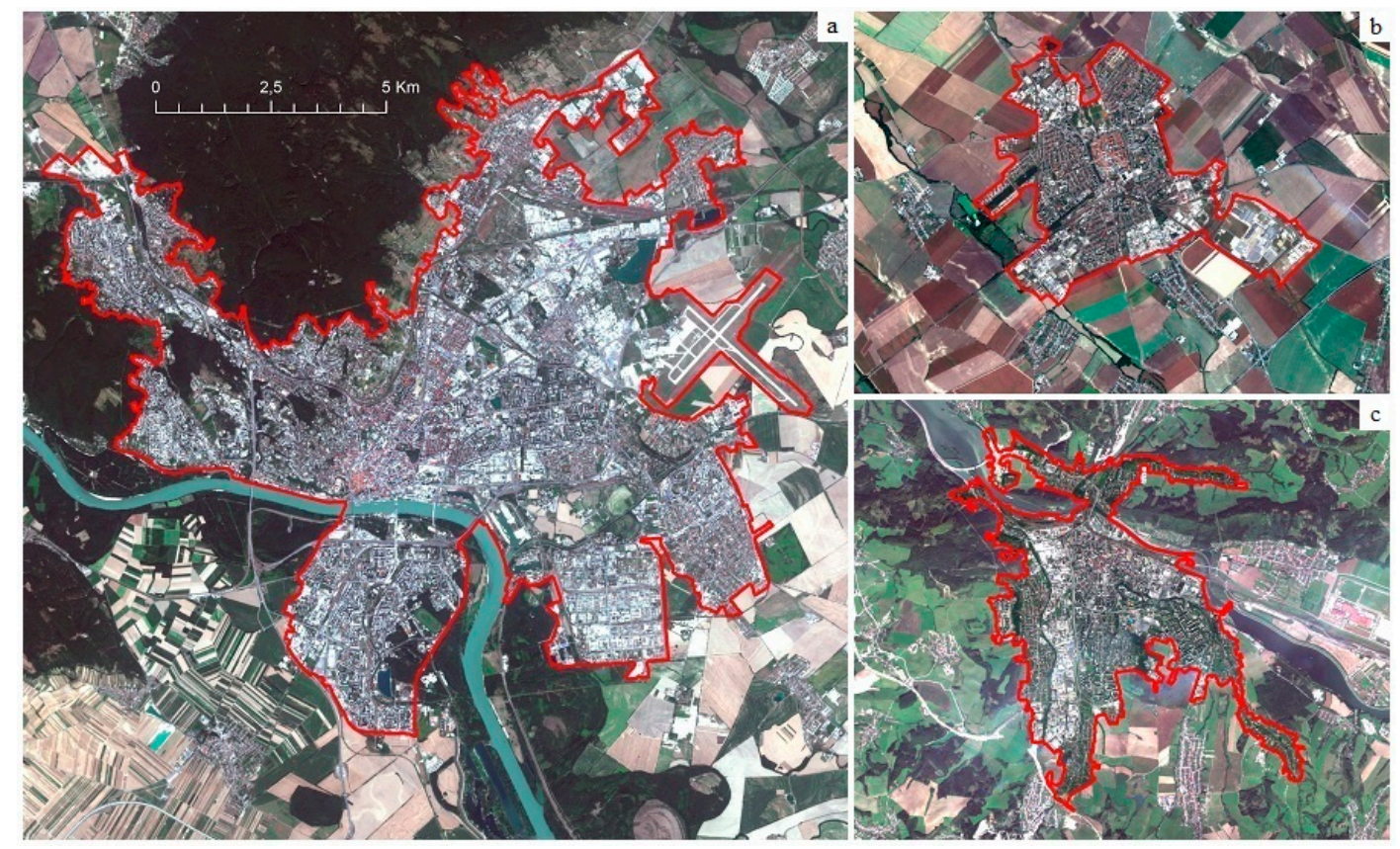

Figure 4. True colour composites (bands 4, 3, and 2 of cloud-free S2A images) of Bratislava (a), Trnava (b) and Žilina (c) study areas.

\section{Results}

The city of Bratislava is a densely populated capital city situated on both banks of a large river. According to the results of initial land cover classification, impervious surfaces covered $51.6 \%$ of the territory, urban vegetation covered $46.5 \%$ (out of which trees covered around $54 \%$ ), and water covered $1.9 \%$. Currently, the UGS area per capita is $121 \mathrm{~m}^{2}$.

The largest part was covered by the class Urban greenery in family housing areas (7) with an area of more than 1000 ha, in total over $20 \%$ of the urban greenery (Table 3). UGS defined as Urban greenery in apartment housing areas (class 6) covered the second largest area of almost 680 ha, i.e., $13.2 \%$ of UGS. However, this class was represented by the highest number of patches ( 823 out of total number 2909 UGS polygons). On the other hand, the class Urban public garden (4) covered the smallest part of green areas within the city. Table 4 provides insight into the tree cover percentage for each class. 
The highest proportions of woody vegetation were detected in class Urban forest / Uncultivated park (1) and Cemeteries (3). The lowest share of woody vegetation was found in class 14-Airport greenery (0.5\%).

Table 3. UGS classification in Bratislava, Trnava and Žilina.

\begin{tabular}{|c|c|c|c|c|c|c|c|c|c|}
\hline \multirow{2}{*}{ UGS Class } & \multicolumn{3}{|c|}{ Polygon Count } & \multicolumn{3}{|c|}{ Class Area (Ha) } & \multicolumn{3}{|c|}{ Class Abundance (\%) } \\
\hline & Bratislava & Trnava & $\overline{\text { Žilina }}$ & Bratislava & Trnava & $\overline{\text { Žilina }}$ & Bratislava & Trnava & Žilina \\
\hline 1 & 36 & 6 & 13 & 469.55 & 29.71 & 67.06 & 9.2 & 4.0 & 6.1 \\
\hline 2 & 39 & 19 & 3 & 74.63 & 43.94 & 9.82 & 1.5 & 6.0 & 0.9 \\
\hline 3 & 10 & 7 & 12 & 58.57 & 6.51 & 11.97 & 1.1 & 0.9 & 1.1 \\
\hline 4 & 7 & 3 & 2 & 12.43 & 2.54 & 1.22 & 0.2 & 0.3 & 0.1 \\
\hline 5 & 64 & 5 & 29 & 149.54 & 8.29 & 59.87 & 2.9 & 1.1 & 5.4 \\
\hline 6 & 823 & 151 & 112 & 679.34 & 73.96 & 139.27 & 13.2 & 10.0 & 12.6 \\
\hline 7 & 589 & 215 & 120 & 1035.07 & 130.67 & 466.27 & 20.2 & 17.7 & 42.2 \\
\hline 8 & 292 & 99 & 90 & 358.40 & 48.40 & 78.54 & 7.0 & 6.6 & 7.1 \\
\hline 9 & 67 & 16 & 11 & 136.92 & 30.65 & 15.61 & 2.7 & 4.2 & 1.4 \\
\hline 10 & 53 & 5 & 15 & 434.44 & 6.78 & 71.19 & 8.5 & 0.9 & 6.4 \\
\hline 11 & 58 & 30 & 5 & 446.98 & 64.25 & 11.49 & 8.7 & 8.7 & 1.0 \\
\hline 12 & 305 & 64 & 63 & 285.94 & 45.57 & 86.99 & 5.6 & 6.2 & 7.9 \\
\hline 13 & 442 & 129 & 97 & 454.23 & 164.48 & 35.15 & 8.9 & 22.3 & 3.2 \\
\hline 14 & 27 & 0 & 0 & 287.82 & 0.00 & 0.00 & 5.6 & 0.0 & 0.0 \\
\hline 15 & 97 & 47 & 41 & 243.48 & 82.06 & 51.37 & 4.7 & 11.1 & 4.6 \\
\hline Total & 2909 & 796 & 613 & 5127.34 & 737.82 & 1105.82 & 100.0 & 100.0 & 100.0 \\
\hline
\end{tabular}

Table 4. Tree cover percentage and average patch size within UGS classes.

\begin{tabular}{cccccccc}
\hline \multirow{2}{*}{ UGS Class } & \multicolumn{2}{c}{ Tree Cover Percentage (\%) } & & \multicolumn{3}{c}{ Average Patch Size (Ha) } \\
\cline { 2 - 3 } & Bratislava & Trnava & Žilina & & Bratislava & Trnava & Žilina \\
\hline 1 & 92.9 & 74.6 & 65.7 & & 13.04 & 4.95 & 5.16 \\
2 & 84.9 & 59.0 & 49.9 & & 1.91 & 2.31 & 3.27 \\
3 & 88.4 & 58.9 & 19.0 & & 5.86 & 0.93 & 1.00 \\
4 & 71.5 & 42.4 & 0.0 & & 1.78 & 0.85 & 0.61 \\
5 & 81.7 & 22.4 & 8.7 & & 2.34 & 1.66 & 2.06 \\
6 & 67.2 & 38.0 & 2.4 & & 0.83 & 0.49 & 1.24 \\
7 & 57.5 & 19.3 & 3.2 & & 1.76 & 0.61 & 3.89 \\
8 & 57.5 & 34.4 & 2.9 & & 1.23 & 0.49 & 0.87 \\
9 & 33.4 & 7.9 & 2.4 & & 2.04 & 1.92 & 1.42 \\
10 & 51.4 & 2.7 & 23.3 & & 8.20 & 1.36 & 4.75 \\
11 & 13.0 & 3.4 & 1.6 & & 7.71 & 2.14 & 2.30 \\
12 & 66.0 & 29.2 & 1.9 & & 0.94 & 0.71 & 1.38 \\
13 & 36.7 & 8.0 & 0.3 & & 1.03 & 1.28 & 0.36 \\
14 & 0.5 & 0.0 & 0.0 & & 10.66 & 0.00 & 0.00 \\
15 & 43.0 & 8.7 & 8.4 & & 2.51 & 1.75 & 1.25 \\
\hline Total & 53.2 & 22.1 & 9.0 & & 1.76 & 0.93 & 1.80 \\
\hline
\end{tabular}

Trnava is a compact city with the highest share of impervious surfaces-over 59\%. The city has the lowest UGS area per capita-112 $\mathrm{m}^{2}$. The tree cover percentage is markedly lower than in Bratislava- $22.1 \%$ of UGS. Green areas in industrial units (class 13) has the highest UGS class abundance (over 22\%), which is affected mainly by large land areas used during the construction of the automobile factory in the south-east part of the city. The second largest area is covered by Urban greenery in family housing areas (class abundance is $17.7 \%$ and it has the highest number of polygons, see Table 3 ). However, private gardens in Trnava are relatively fragmented-the average patch size is only 0.61 ha (compared to 1.76 ha in Bratislava and 3.89 ha in Žilina).

The total green space within the city of Žilina amounts to 1120 ha, representing $50.64 \%$ of the city area. The city has the highest area of UGS per capita-136 $\mathrm{m}^{2}$. However, UGS tree cover percentage is 
the lowest-only $9 \%$. Residential gardens (class 7 ) represent as much as $42 \%$ of urban greenery area in the city. Although often ignored by ecologists as significant habitats in urban landscapes, gardens contribute to plant species richness and to insect and avian species diversity by providing critical habitat for nesting, food, and cover [4]. From this point of view, relatively compact class area plays the important role. As in Bratislava, the second largest area is covered by Urban greenery in apartment housing area with similar class abundance $12.6 \%$ (Figure 5). These two cities have also similar UGS average patch size-Žilina 1.80 ha and Bratislava 1.76 ha.

Woody vegetation is necessary for urban heat mitigation and improves the quality of life in residential areas. The share of tree cover in apartment housing areas (class 6) varies considerably in the cities-it is the highest in Bratislava (67.2\%), much lower in Trnava (38\%) and extremely low in Žilina (2.4\%). Similar differences in tree cover percentage were recorded in family housing areas (class 7) - Bratislava $57.5 \%$, Trnava $19.3 \%$ and Žilina $3.2 \%$; as well as in the surroundings of public facilities (class 8 ). The regulative function of woody vegetation is especially important along roads in the cities. While tree cover percentage in roadside greenery (class 12) in Bratislava is 66\%, in Žilina it accounts only for $1.9 \%$ of the class area.

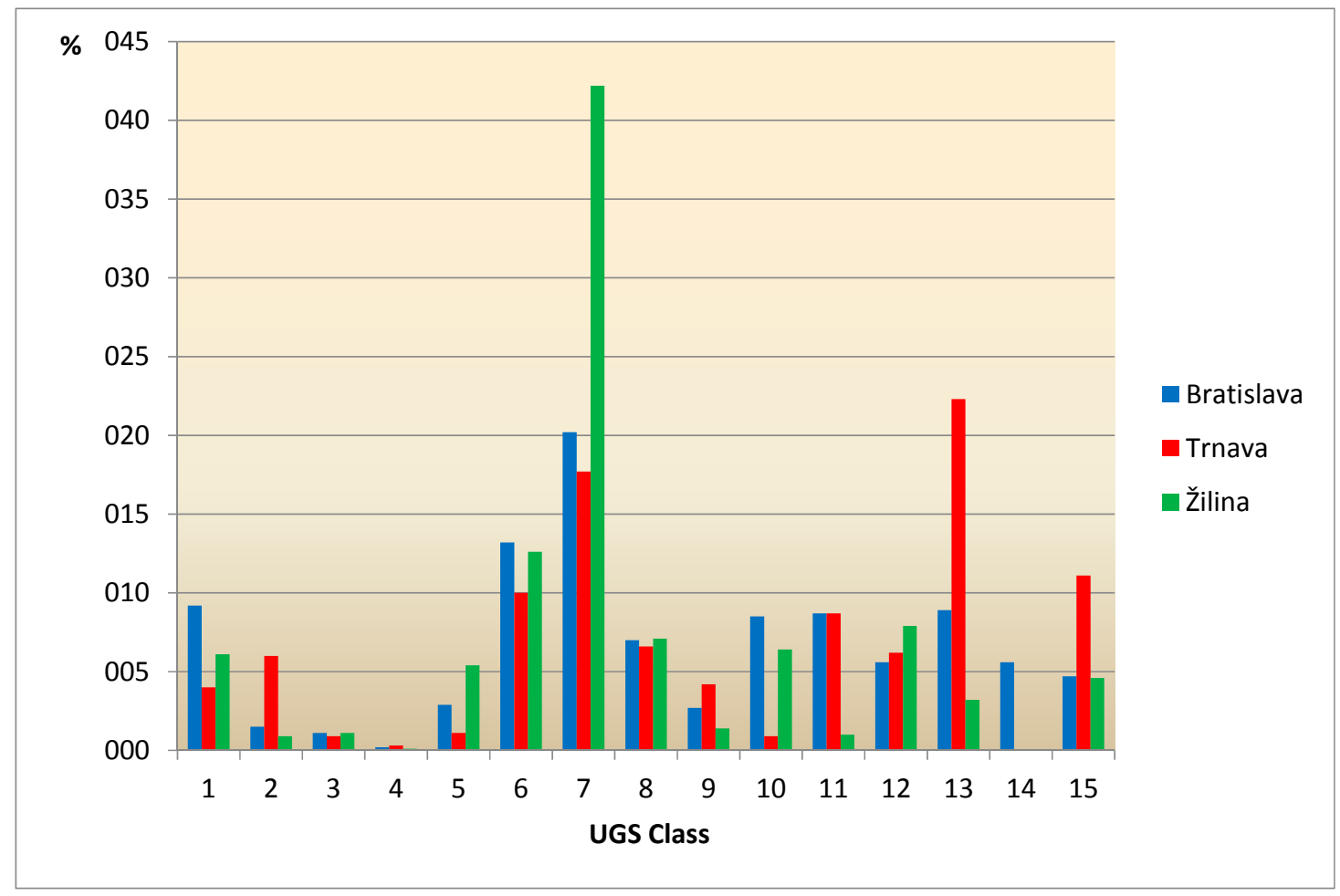

Figure 5. Proportion of UGS classes (\%) in Bratislava, Trnava and Žilina.

The process of urbanisation transforms the original landscapes. It fragments natural vegetation resulting in habitat loss and isolation. Assessments of patches of remnant vegetation show that patch configuration plays a significant role in determining plant species [4]. In general, larger remnant patches contain more native species than smaller patches in urban landscapes. Consequently, conservation strategies in urban landscapes favour preserving larger patches over smaller ones. More than $12 \%$ of the green space in Bratislava corresponds to the areas with important habitat ecosystem services with a high proportion of natural vegetation. The average patch size for Urban forest/Uncultivated park and shore vegetation was 13.04 ha and 2.34 ha, respectively. The map of urban greenery presented in Figure 6 provides information about the spatial distribution of the ecosystem services within the city. 


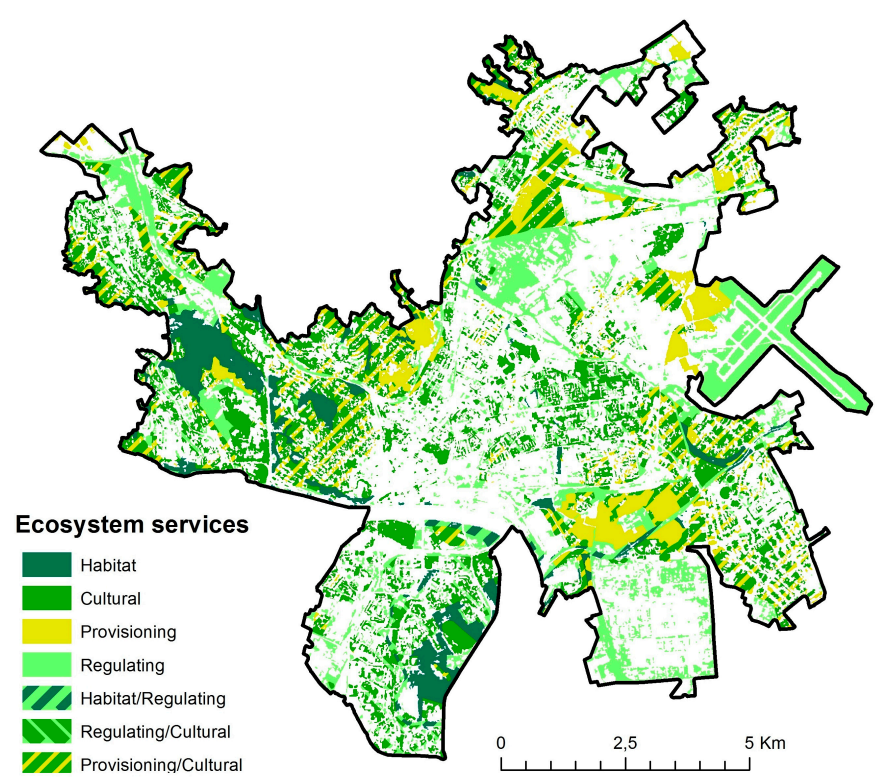

Figure 6. Ecosystem services in the city of Bratislava.

In Trnava, only limited amounts of the UGS correspond to urban forests or shore vegetation with the important habitat ecosystem services (ca. 5\%). In Figure 7, areas with regulating ecosystem services dominate. In the city of Žilina (Figure 8), UGS with multifunctional ecosystem services cover the largest part of the territory.

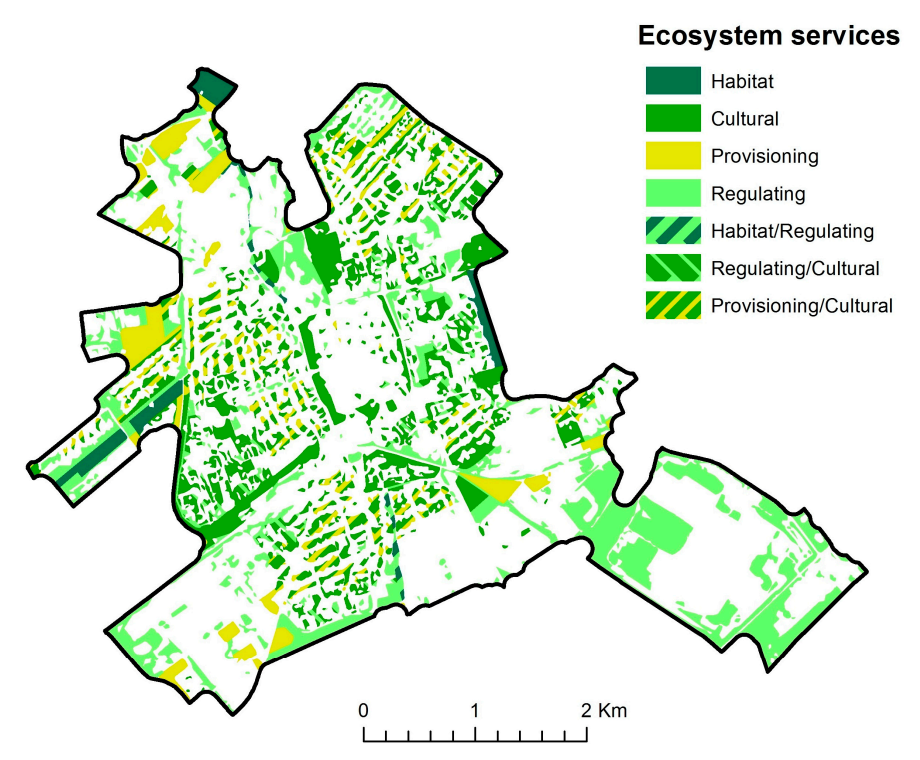

Figure 7. Ecosystem services in the city of Trnava.

As the central parts of the cities with densely built-up historical cores mostly lack UGS, the absence of ecosystem services is significant in the maps shown in Figures 6-8. Near the historical centres, small fragmented areas with cultural ecosystem services prevail. Multifunctional fragments of UGS are a typical feature of the urban landscape in residential zones adjacent to the city centre. Similar patterns can also be found in urban quarters that used to be separate villages in the past. Larger areas with cultural ecosystem services, such as parks, are located irregularly in different parts of the cities. Plots with production function are usually situated farther from the city centre and they often represent the localities of future development. UGS with regulating services are scattered along 
the roads throughout the cities; larger compact areas can be found in the periphery (industrial zones and the airport).

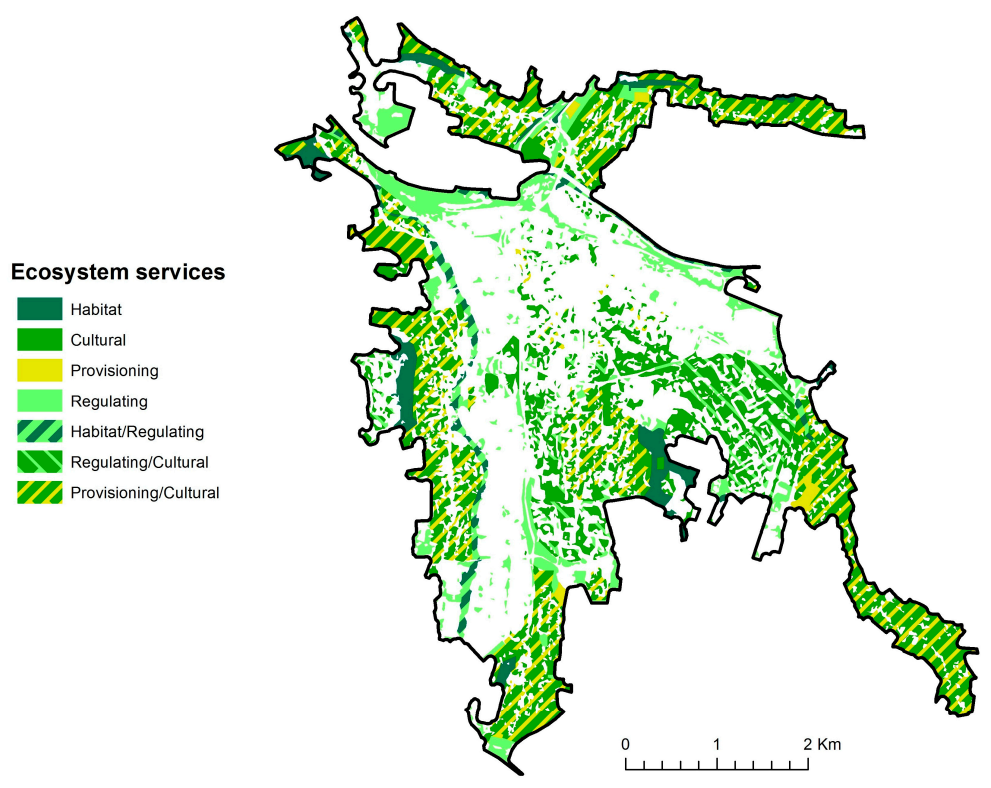

Figure 8. Ecosystem services in the city of Žilina.

\section{Discussion}

\subsection{Processing of Sentinel-2A Data}

The Sentinel-2 mission establishes a key European source of data for the Copernicus environmental monitoring program. Based on visual inspection of the results and comparison with VHR imagery, the overall quality of UGS extraction seems to be satisfactory. However, the distinction between tree and non-woody vegetation may be subject to commission and omission errors. The distinction is rather of continuous than binary nature since there are many tree, shrub, and other plant species of various ages and phenological phases. The amount of tree cover can also be biased by the number, location, and selection of training samples.

The results of post-classification accuracy assessment (Table 1) show good overall accuracy (over $85 \%$ ). Although at the class level, as expected, there is confusion mainly between the two classes of vegetation. This has implications for the reported share of tree cover (Table 4). While in Bratislava there was commission error of $24 \%$, in Trnava and Žilina, respective omission errors of $17 \%$ and $29 \%$ were estimated for the tree cover class. A likely source of the error is the temporal difference between the classified image and image used for finding the ground truth, as well as inaccuracies in delineation and classification of the training samples. Consequently, the actual cover tree cover percentage in the study areas may differ from the reported values, but we do not expect that ranking of the study areas would change (adjusted values of tree cover percentage: Bratislava 40\%, Trnava 26\% and Žilina 13\%).

In addition, the morphology of the urban fabric may affect the results. In data derived from remote sensing, the classes that are dominant in a particular area tend to be overestimated and vice versa [29]. This effect is caused by cross-pixel spectral contamination (backscattered radiation from adjacent pixels influences the spectral response of a given pixel). Thus, cities with more fragmented UGS can be underestimated. With increasing fragmentation and heterogeneity of the urban landscape, the proportion of mixed pixels increases (when 10 or $20 \mathrm{~m}$ pixels are considered), and the accuracy of classification decreases. Five-metre resolution satellite data would be perhaps more suitable for UGS mapping. However, the wide swath, frequent revisit, spectral richness, and free availability of S2A data makes them very worthwhile to investigate their potential for monitoring built-up areas [30]. 


\subsection{Assessment of Urban Ecosystem Services}

Rapid urbanisation provides multiple opportunities to ensure basic human welfare and a viable global environment. According to some prognosis, more than 60 percent of the area projected to be urban in 2030 has yet to be built, and this presents opportunities to improve global sustainability, exploring how cities can be responsible stewards of biodiversity and ecosystem services within city boundaries [31]. With the growing awareness of the value of biodiversity and ecosystem services, cities should ensure that their biodiversity is conserved. Based on our results, specific management schemes and tools can be recommended for areas with various ecosystem services. For example, management policies could include leaving certain areas unmanaged (classes 1 and 5) while some areas could be managed lightly (class 3 ) and the others more intensively (classes 4 or 9). The spatially detailed and up to date information on the status of urban vegetation enables more efficient spending of limited resources by prioritisation and targeting neighbourhoods with least sufficient vegetation. Especially in combination with other data sources, it is possible to obtain valuable insights. For instance, together with demographic data, one can target vulnerable zones with a high proportion of elderly people sensitive to heat waves and an insufficient amount of tree coverage. Combined with noise exposure maps, the results could help improve roadside vegetation where most needed. Urban planners can also implement this information in planning frameworks including greenery coefficients (minimal share of vegetation per zone) or built-up indices.

Biodiversity studies in urban areas are often conducted in public spaces where access is not limited. However, comparative analysis of the three cities indicated the relatively high importance of the class Urban greenery in family housing areas, represented mainly by privately owned gardens. By controlling the vegetation structure in their properties, the private owners can have a major influence on urban biodiversity. Our results confirm the outputs of Goddard et al. [32] who point out the fact that in many countries, private gardens are a major component of urban green space and can provide considerable biodiversity benefits. They describe existing garden conservation strategies and the importance of gardens for raising awareness about biodiversity and public understanding of science. They also argue that citizens have a huge potential for enhancing urban environments by coordinating public management actions. The importance of privately managed UGS was confirmed also by Andersson et al. [33], who examined the importance of management scale on diversity and subsequently on ecosystem services in Stockholm, Sweden. They focused on three types of green spaces in Stockholm, Sweden: parks, managed by the city; cemeteries, generally managed by the Church of Sweden; and allotment gardens, managed by individuals. Those systems managed by individuals—bottom up management—had the greatest diversity and abundance of pollinators and a different suite of seed dispersers and insectivores than systems managed by the city and the Church of Sweden-top-down management. In this context, local authorities in the study areas should support environmental awareness and they can motivate local people to get involved in biodiversity measures. In Slovakia, all the garden parcels are subject to real estate tax defined by the municipality, so the tax reduction for the gardens with natural full-grown trees could be one of the suitable tools.

The presented maps in Figures 6-8 reflect dominant ecosystem services as defined in the TEEB Manual for Cities [13]. However, many UGS are multifunctional. Because city environments may be stressful for inhabitants, the recreational aspects of urban ecosystems are among the highest valued ecosystem services in cities. Nevertheless, cultivated parks are not only credited for their cultural ecosystem services and positive aesthetic and social values $[34,35]$ but also act as hot spots of biodiversity in urban areas [36]. Similarly, together with cultural and provisioning ecosystem services, gardens provide habitat for many synanthropic species and support biodiversity [32]. Therefore, preservation of different types of UGS, including allotments and privately owned gardens, could be a target goal for urban planning initiatives in Slovak cities. Our recent land cover change analysis between the years 2002 and 2011 in Trnava based on VHR satellite data [37] documented not only intensive urban extension but also significant urban infill (UGS replaced by built-up areas). Presented results can serve as input data for the continuous monitoring of urban greenery in all three 
cities. Sentinel 2 imagery in the next years will allow us to monitor changes in the size and spatial structure of UGS classes and to evaluate the rate of urban infill. Although the initial classification of automatically extracted polygons is somewhat laborious, it is much less so for the future updates of the maps in which only a limited part of the polygons will need to be edited.

It is well known that vegetation abundance is negatively correlated to land surface temperature. Clustered or less fragmented UGS patterns lower surface temperature more effectively than dispersed patterns [38]. Based on our results, the UGS in Trnava study area are more fragmented than in Bratislava and Žilina. Another factor affecting the local microclimate is the tree cover proportion. While we have found that it is very low in Žilina, the city is also less prone to experiencing heatwaves compared to the other two study areas-thanks to its basin location and higher elevation, the average high temperatures in summer are around $2{ }^{\circ} \mathrm{C}$ lower. Presented results of UGS assessment will serve as the input data for the definition of the local climate zones [39], and the MUKLIMO model [40,41] will be tested in the study areas. Further research oriented on the relationship between the spatial pattern of urban features and land surface temperature in the study areas will bring deeper insight into the effects of UGS on local urban microclimate.

\section{Conclusions}

UGS developing and planning green spaces is of great importance in urban planning because it provides a wide range of ecosystem services, reduces the urban heat island, cleans the urban air, dampens noise, and absorbs $\mathrm{CO}_{2}$. Land cover indices derived from remote sensing are crucial urban indicators, which contribute to sustainable urban planning and management. The recent availability of Sentinel-2 data is expected to bring land cover mapping and UGS monitoring to an unprecedented level. Among the main advantages of Sentinel-2, which make the satellite suitable for mapping and monitoring human settlements at a global level, is the combination of the wide swath and the frequent revisiting time at relatively high spatial resolutions. The results presented in this paper demonstrate the added-value of Sentinel-2 for mapping built-up areas in the context of ecosystem mapping and assessment. Current knowledge of ecosystem patterns and processes linked with landscape design enables not only planners and managers but also individual land owners to build sustainable landscapes for humans as well as urban flora and fauna. Presented comparative analyses of Bratislava, Trnava and Žilina can serve as a reference for decision- and policymakers in preserving urban biodiversity and improving life quality as well as the basis for other environmental research in these cities.

Acknowledgments: This paper is one of the outputs of the following projects: "Effect of impermeable soil cover on urban climate in the context of climate change" (Slovak Research and Development Agency-Grant Agency No. APVV-15-0136) and Changes in Agricultural Land Use: Assessment of the Dynamics and Causes Applying Land Cover Data and Selected Environmental Characteristics (VEGA-Grant Agency No. 2/0096/16) pursued at the Institute of Geography of the Slovak Academy of Sciences.

Author Contributions: Monika Kopecká conceived the UGS classification and wrote the paper; Konštantín Rosina proposed the methodology of UGS extraction and together with Monika Kopecká, analysed the data for the Bratislava study area; Daniel Szatmári analysed the data for Trnava and Žilina and prepared the figures.

Conflicts of Interest: The authors declare no conflict of interest.

\section{References}

1. European Environmental Agency. Urban Sprawl in Europe. The Ignored Challenge; EEA Report No. 10/2006; Office for Official Publications of the European Communities: Luxembourg, 2006; p. 56.

2. Soukup, T.; Feranec, J.; Hazeu, G.; Jaffrain, G.; Jindrova, M.; Kopecky, M.; Orlitova, E. Corine Land Cover 1990 (CLC 1990): Analysis and Assessment. In European Landscape Dynamics: Corine Land Cover Data; Feranec, J., Soukup, T., Hazeu, G., Jaffrain, G., Eds.; CRC Press: Boca Raton, FL, USA, 2016; pp. 69-76.

3. Grimm, N.B.; Faeth, S.H.; Golubiewski, N.E.; Redman, C.L.; Wu, J.; Bai, X.; Briggs, J.M. Global change and the ecology of cities. Science 2008, 319, 756-760. [CrossRef] [PubMed] 
4. Müller, N.; Ignatieva, M.; Nilon, C.H.; Werner, P.; Zipperer, W.C. Patterns and Trends in Urban Biodiversity and Landscape Design. In Urbanization, Biodiversity and Ecosystem Services: Challenges and Opportunities: A Global Assessment; Elmqvist, T., Fragkias, M., Goodness, J., Güneralp, B., Marcotullio, P.J., McDonald, R.I., Parnell, S., Schewenius, M., Sendstad, M., Seto, K.C., et al., Eds.; Springer: Dordrecht, The Netherlands; Heidelberg, Germany; New York, NY, USA; London, UK, 2013; pp. 123-174.

5. Schmid, J.A. Urban Vegetation: A Review and Chicago Case Study; Department of Geography Research Paper No. 161; University of Chicago: Chicago, IL, USA, 1975; p. 266.

6. Whitney, G.G.; Adams, S.D. Man as a maker of new plant communities. J. Appl. Ecol. 1980, 17, 431-448. [CrossRef]

7. Hard, G. Vegetationsgeographie and Sozialökologie einer Stadt. Ein Vergleich zweier, Städtplane am Beispiel von Osnabrück. Geographische Zeitschrift 1985, 73, 125-144.

8. Lehman, I.; Mathey, J.; Rößler, S.; Bräuer, A.; Goldberg, V. Urban vegetation structure types as a methodological approach for identifying ecosystem services-Application to the analysis of micro-climatic effects. Ecol. Indic. 2014, 42, 58-72. [CrossRef]

9. Wolch, J.R.; Byrne, J.; Newell, J.P. Urban green space, public health and environmental justice: The challenge of making cities just green enough. Landsc. Urban Plan. 2014, 125, 234-244. [CrossRef]

10. Tzoulas, K.; Korpela, K.; Venn, S.; Yli-Pelkonen, V.; Kazmiercak, A.; Niemelä, J.; James, P. Promoting ecosystem and human health in urban areas using Green infrastructure. A literature review. Landsc. Urban Plan. 2007, 81, 167-178. [CrossRef]

11. Niemela, J. Ecology of urban green spaces: The way forward in answering major research questions. Landsc. Urban Plan. 2014, 125, 298-303. [CrossRef]

12. Maas, J.; Verheij, R.A.; Groenewegen, P.P.; Vries, S.; Spreeuwenberg, P. Green space, urbanity, and health: How strong is the relation? J. Epidemiol. Community Health 2006, 60, 587-592. [CrossRef] [PubMed]

13. TEEB-The Economics of Ecosystems and Biodiversity. TEEB Manual for Cities: Ecosystem Services in Urban Management; TEEB: Geneva, Switzerland, 2011; p. 43. Available online: www.teebweb.org (accessed on 20 February 2017).

14. Cheng, C.; Li, B.; Ma, T. The application of very high resolution satellite image in urban vegetation cover investigation: A case study of Xiamen City. J. Geogr. Sci. 2003, 13, 265-270.

15. Nichol, J.; Lee, C.M. Urban vegetation monitoring in Hong Kong using high resolution multispectral images. Int. J. Remote Sens. 2005, 26, 903-918. [CrossRef]

16. Tigges, J.; Lakes, T.; Hostert, P. Urban vegetation classification: Benefits of multitemporal RapidEye satellite data. Remote Sens. Environ. 2013, 136, 66-75. [CrossRef]

17. Rosina, K.; Kopecká, M. Mapping of urban green spaces using Sentinel-2A data: Methodical aspects. In Proceedings of the 6th International conference on cartography and GIS, Albena, Bulgaria, 13-17 June 2016.

18. Ulrich, R.S. Natural versus urban sciences: Some psycho-physiological effects. Environ. Behav. 1981, 13, 523-556. [CrossRef]

19. Kaplan, R. The analysis of perception via preference: A strategy for studying how the environment is experienced. Landsc. Urban Plan. 1983, 12, 161-176. [CrossRef]

20. Gómez-Baggethun, E.; Gren, A.; Barton, D.N.; Langemeyer, J.; McPhearson, T.; O’Farrell, P.; Andersson, E.; Hamstead, Z.; Kremer, P. Urban Ecosystem Services. In Urbanization, Biodiversity and Ecosystem Services: Challenges and Opportunities: A Global Assessment; Elmqvist, T., Fragkias, M., Goodness, J., Güneralp, B., Marcotullio, P.J., McDonald, R.I., Parnell, S., Schewenius, M., Sendstad, M., Seto, K.C., et al., Eds.; Springer: Dordrecht, The Netherlands; Heidelberg, Germany; New York, NY, USA; London, UK, 2013; pp. 175-252.

21. Moreno-Garcia, M.C. Intensity and form of the urban heat island in Barcelona. Int. J. Climatol. 1994, 14, 705-710. [CrossRef]

22. Nowak, D.J.; Crane, D.E. Carbon storage and sequestration by urban trees in the USA. Environ. Pollut. 2002, 116, 381-389. [CrossRef]

23. Wang, Y.; Bakker, F.; de Groot, R.; Wortche, H.; Leemans, R. Effects of urban trees on local outdoor microclimate: Synthesizing field measurements by numerical modelling. Urban Ecosyst. 2015, 18, 1305-1331. [CrossRef]

24. Ulrich, R.S. View through a window may influence recovery from surgery. Science 1984, $224,420-421$. [CrossRef] [PubMed] 
25. Van den Berg, A.E.; van Winsum-Westra, M.; de Vries, S.; van Dillen, S.M.E. Allotment gardening and health: A comparative survey among allotment gardeners and their neighbors without an allotment. Environ. Health 2010, 9, 74. [CrossRef] [PubMed]

26. Kiss, M.; Takács, A.; Pogacsas, R.; Gulyas, A. The role of ecosystem services in climate and air quality in urban areas: Evaluating carbon sequestration and air pollution removal by street and park trees in Szeged (Hungary). Morav. Geogr. Rep. 2015, 23, 36-46. [CrossRef]

27. Vatseva, R.; Kopecká, M.; Otahel, J.; Rosina, K.; Kitev, A.; Genchev, S. Mapping urban green spaces based on remote sensing data: Case studies in Bulgaria and Slovakia. In Proceedings of the 6th International Conference on Cartography and GIS, Albena, Bulgaria, 13-17 June 2016.

28. European Commission: Mapping Guide for a European Urban Atlas. Available online: https:// cws-download.eea.europa.eu/local/ua2006/Urban_Atlas_2006_mapping_guide_v2_final.pdf (accessed on 19 February 2017).

29. Hurbanek, P.; Atkinson, P.M.; Chockalingam, J.; Pazúr, R.; Rosina, K. Accuracy of Built-up Area Mapping in Europe at Varying Scales and Thresholds. In Proceedings of the Accuracy 2010: Ninth International Symposium on Spatial Accuracy Assessment in Natural Resources and Environmental Sciences, Leicester, UK, 20-23 July 2010; pp. 385-388.

30. Pesaresi, M.; Corbane, C.; Julea, A.; Florczyk, A.J.; Syrris, V.; Soille, P. Assessment of the added-value of Sentinel-2 for detecting built-up areas. Remote Sens. 2016, 8, 299. [CrossRef]

31. Elmqvist, T.; Fragkias, M.; Goodness, J.; Güneralp, B.; Marcotullio, P.J.; McDonald, R.I.; Parnell, S.; Schewenius, M.; Sendstad, M.; Seto, K.C.; et al. (Eds.) Urbanization, Biodiversity and Ecosystem Services: Challenges and Opportunities: A Global Assessment; Springer: Dordrecht, The Netherlands; Heidelberg, Germany; New York, NY, USA; London, UK, 2013; p. 755.

32. Goddard, M.A.; Dougill, A.J.; Benton, T.G. Scaling up from gardens: Biodiversity conservation in urban environments. Trends Ecol. Evol. 2009, 25, 90-98. [CrossRef] [PubMed]

33. Andersson, E.; Barthel, S.; Ahrné, K. Measuring social-ecological dynamics behind the generation of ecosystem services. Ecol. Appl. 2007, 17, 1267-1278. [CrossRef] [PubMed]

34. Bolund, P.; Hunhammar, S. Ecosystem services in urban areas. Ecol. Econ. 1999, 29, 293-301. [CrossRef]

35. Chiesura, A. The role of urban parks for the sustainable city. Landsc. Urban Plan. 2004, 68, 129-138. [CrossRef]

36. Cornelis, J.; Hermy, M. Biodiversity relationships in urban and suburban parks in Flanders. Landsc. Urban Plan. 2004, 69, 385-401. [CrossRef]

37. Kopecká, M.; Rosina, K. Identifikácia zmien urbanizovanej krajiny na báze satelitných dát s vel'mi vysokým rozlíšením (VHR): Záujmové územie Trnava. Geografický časopis 2014, 66, 247-267.

38. Fan, C.; Myint, S.W.; Zheng, B. Measuring the spatial arrangement of urban vegetation and its impacts on seasonal surface temperatures. Prog. Phys. Geogr. 2015, 39, 199-219. [CrossRef]

39. Stewart, I.D.; Oke, T.R. Local Climate Zones for urban temperature studies. Bull. Am. Meteorol. Soc. 2012, 93, 1879-1900. [CrossRef]

40. Sievers, U.; Zdunkowski, W. A microscale urban climate model. Contributions to atmospheric physics/Beiträge Zur Physik Der Atmosphäre 1986, 59, 13-40.

41. Geletic, J.; Lehnert, M.; Dobrovolný, M. Modelled spatio-temporal variability of air temperature in an urban climate and its validation: A case study of Brno, Czech Republic. Hung. Geogr. Bull. 2016, 65, 169-180. [CrossRef]

(c) 2017 by the authors. Licensee MDPI, Basel, Switzerland. This article is an open access article distributed under the terms and conditions of the Creative Commons Attribution (CC BY) license (http:/ / creativecommons.org/licenses/by/4.0/). 